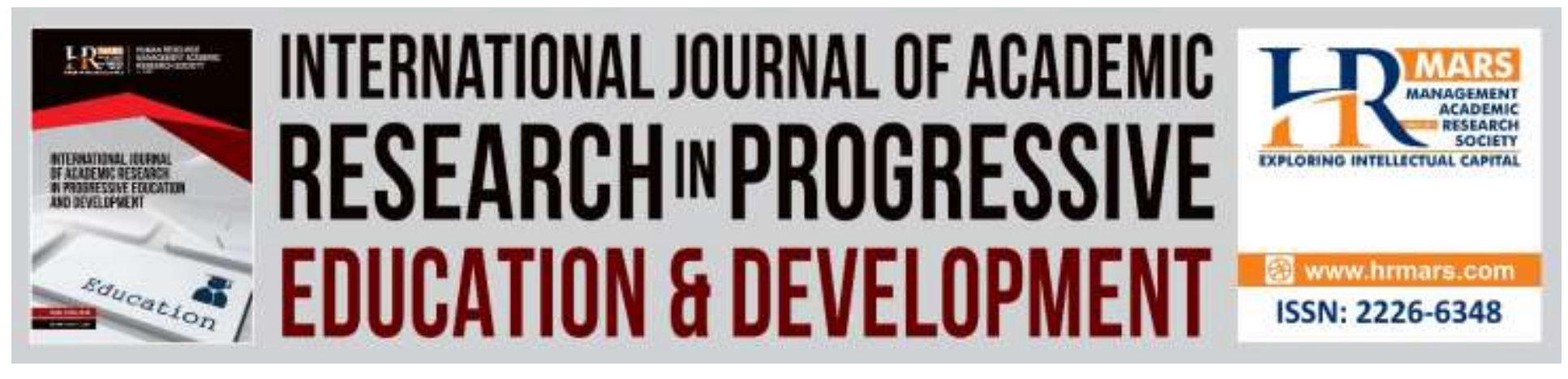

\title{
A Systematic Review of the Psychological Capital (PsyCap) Research Development: Implementation and Gaps
}

\author{
Nur Aimi Nasuha Burhanuddin, Nor Aniza Ahmad, Rozita Radhiah Said, \\ Soaib Asimiran
}

To Link this Article: http://dx.doi.org/10.6007/IJARPED/v8-i3/6302

DOI: $10.6007 /$ IJARPED/v8-i3/6302

Received: 10 July 2019, Revised: 18 August 2019, Accepted: 03 September 2019

Published Online: 23 September, 2019

In-Text Citation: (Burhanuddin, Ahmad, Said, \& Asimiran, 2019)

To Cite this Article: Burhanuddin, N. A. N., Ahmad, N. A., Said, R. R., \& Asimiran, S. (2019). A Systematic Review of the Psychological Capital (PsyCap) Research Development: Implementation and Gaps. International Journal of Academic Research in Progressive Education and Development, 8(3), 133-150.

Copyright: (C) 2019 The Author(s)

Published by Human Resource Management Academic Research Society (www.hrmars.com)

This article is published under the Creative Commons Attribution (CC BY 4.0) license. Anyone may reproduce, distribute, translate and create derivative works of this article (for both commercial and non-commercial purposes), subject to full attribution to the original publication and authors. The full terms of this license may be seen at: http://creativecommons.org/licences/by/4.0/legalcode

Vol. 8(3) 2019, Pg. 133 - 150

http://hrmars.com/index.php/pages/detail/IJARPED

JOURNAL HOMEPAGE

Full Terms \& Conditions of access and use can be found at http://hrmars.com/index.php/pages/detail/publication-ethics 


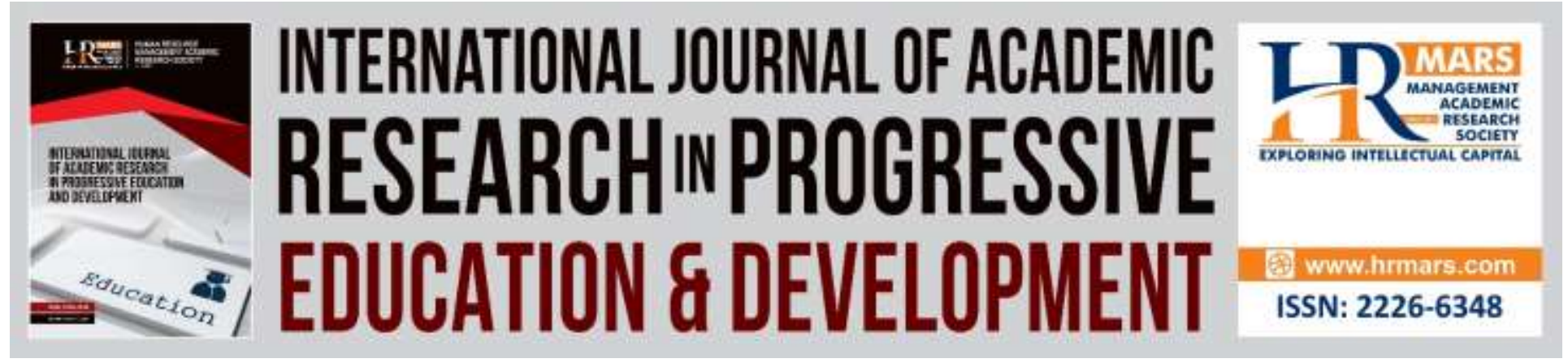

\title{
A Systematic Review of the Psychological Capital (PsyCap) Research Development: Implementation and Gaps
}

\section{Nur Aimi Nasuha Burhanuddin, Dr. Nor Aniza Ahmad, Dr. Rozita Radhiah Said, Dr. Soaib Asimiran}

Faculty of Educational Studies, Universiti Putra Malaysia, 43400 Serdang, Selangor, Malaysia Email:nor_aniza@upm.edu.my

\begin{abstract}
A systematic review was conducted to investigate the literature on the psychological capital (PsyCap) research development. Four databases (ProQuest, EBSCOhost, Springer and Emerald Insight) were systematically searched to identify relevant articles published between 2008 and 2018. Findings revealed that research on PsyCap within educational organizations is still in its early stage. Most were done using quantitative methods with the emphasis given to the outcomes of the construct. This review highlighted that PsyCap was researched as predictor for a wide range of academic-related outcome such as engagement, motivation, achievement, performance, teachers' job performance and attitude. This review will contribute to the continuing discussion on PsyCap in educational organization as well as useful to the researchers and policy makers in developing psychological resources within academe. The findings can be used in guiding future research needed to be conducted concerning PsyCap within educational organization by broadening the respondent to beyond teachers and students.
\end{abstract}

Keywords: Psychological Capital, Psycap, Educational Organizations, Systematic Review, Qualitative

\section{Introduction}

At present days, the development of psychological capital (PsyCap) within employee self have gain attention in much literature. Much of the research has found that the development of PsyCap are positively linked with employee work performance that included their engagement to work, job satisfaction, work motivation and etc. The positive result from developing the PsyCap within industrial organization has spurred it needs to be developed within educators as well as the people within the educational organization. The crises and challenges face by people in educational organization is comparable to that in industrial organization. People in educational organization do experienced stress, demotivation, burnout and other negative experiences due to workload they bear. Thus, PsyCap has been identified as an essential psychological resource 
to be develop within educator's self in order to help them to perform better in their job and further help increase student outcome.

There is a growing demand to develop PsyCap within employee self in order to ensure a better work-related outcomes as well as their well-being while preventing the negative consequences resulted from the challenges and workload they faced in work place. Developing PsyCap has been heavily linked with positive results. Despite the positive results shown, little is know about the development of PsyCap within educational organization. Most of the studies done on psychological capital is focusing on industrial organization and it is convinced that the research on the development of psychological capital within educational organization is still scant to date. Therefore, determining the outcome of developing PsyCap within educational organization is essential in order to identify the results it brings to the people in educational organization and further could potentially contribute to a better academic related outcomes. While there are numbers of studies done on PsyCap, further research is required to scrutinize its development and implementation within educational organization. As such, there are need to review the literature systematically in order to synthesize the available research on PsyCap development within educational organization. This will further accelerate our understanding on the impact PsyCap has to those in educational organization as well as if the impact is comparable to those in industrial organization. By doing so, this will allow us to identify research gaps and provide suggestion for future research. Therefore, this paper examines the published literature on the development of PsyCap within educational organizations.

\section{What is Psychological Capital (PsyCap)?}

PsyCap comprises four psychological resources construct of Hope, Optimism, Self-Efficacy and Resilience and that, these four travel together and interact work synergistically, to produce differentiated manifestation overtime and across context (Luthans and Youssef- Morgan 2017). The findings in the literature have shown that developing PsyCap within one self will improve employee job performance and outcome. PsyCap in the form of self-efficacy, optimism, hope and resilience serve certain personal qualities that enable workers to cope better in the workplaces and previous studies have shown that PsyCap positively predicted employee outcomes including work engagement (Avey et al. 2008; Simons and Buitendach 2013), work performance (Luthans et al. 2008), job satisfaction (Luthans et al. 2007a, b, 2008), and organizational citizenship behavior (Beal et al. 2013)

A distinct feature of psychological capital is that it is "state-like" and thus developable and measurable. PsyCap is defined as the study and application of positive oriented human resource strengths and psychological capacities that can be measured, developed, and effectively managed for performance improvement in today's workplace (Luthans, 2002). It emerged as the result of positive psychology movement initiated by Martin Seligman. Luthans (2002) define PsyCap as a concept that goes beyond human capital (what you know), social capital (who you know) and financial capital (what you have). PsyCap is viewed as "who you are" and "who you are becoming". It is a higher-level, core construct that consists of four dimensions of hope, optimism, resilience and self-efficacy. 


\section{Psychological Capital and Its Outcome}

Past studies have linked psychological capital with various range of variable like job commitment and satisfaction, performance in occupational and social status, anxiety, perceived stress, ability to cope with the pressure and problems, happiness and well-being as well as seeking behavior (Golparvar, 2013; Luthans et al., 2005; Luthans, 2002; Luthans, Youseff \& Avolio, 2006). On top of that, it is also postulated that psychological capital improves the value of human capital (individuals' knowledge and skills) and social capital (network of relationships among them) and thus able to reduces the challenges in the organizations by depending on positive psychological variables such as hope and self-efficacy (Luthans et al., 2007). Many studies conducted previously shows that psychological capital has positive links with employee's working environment and other organizational variables. Reports gained indicated that psychological capital plays an important role in combating challenges within organization as well as enhancing employee competencies (Rahimi et al., 2012; Mortazavi et al., 2012; Mahmoodvand, 2013; Alipoor et al., 2013; Gu, 2011; Madden, 2013).

Within business organization, a study done by Nafei (2015) investigating psychological capital (PsyCap) in relation to employee attitudes and performance shows a result that PsyCap is positively related with employee attitude, specifically in their job satisfaction and organizational commitment. Besides that, it was also found that higher the PsyCap will lead to more satisfaction, more commitment and high performance. Although the study was carried out within Egyptian context, the results obtained are parallel with the research conducted by (Luthans et al., 2007; 2008; Avey, et al., 2010; Seligman, 1998; Bandura, 1997; Stajkovic \& Luthans, 1998; Bakker \& Demerouti, 2006; Avey et al., 2009; Avey et al., 2010).

Meanwhile in educational organization, the findings are no different that what has been reported within business organization. Viseu and his colleagues did a research linking PsyCap and teacher's motivation. The study found that PsyCap is strongly related with teacher's motivation (Viseu et al., 2016). They concluded that, teacher's motivation is based on their work satisfaction and by developing PsyCap within teacher's self, they will be more satisfied with their job and hence their motivation will inclined. While Viseu and his colleagues looking at teacher's motivation, another study was also done to explore the links between elements of PsyCap and teacher's effectiveness. The study yield a result that PsyCap have an impact on teaching effectiveness and the higher the PsyCap is, the better the teacher performance in teaching. When teachers teach students, they can have the positive hope and optimism to work. If teachers face difficulties and challenges, they will have the resiliency to do. Therefore, their teaching effectiveness would be better.

The evidence from the study shows that PsyCap have positive links with one's performance in their job, to which it can increase their motivation, satisfaction, commitment, ability to cope with pressure and problems and many other positive outcome. 
Vol. 8, No. 3, 2019, E-ISSN: 2226-6348 @ 2019 HRMARS

\section{Review Methodology}

In order to address the review purpose, the following steps were taken: (1) identify inclusion and exclusion criteria for article selection, (2) identify the relevant work (search strategy), (3) data extraction and quality appraisal of the selected studies, and (3) summary, synthesis and interpretation of the findings (Khan, Kunz, Kleijnen, \& Antes, 2003; Ryan, 2010; Siddaway, 2014; Strech \& Sofaer, 2012). For the purpose of the review, the educational organization encompass all the people who are within the organization that include teachers, lecturers students and administration staff.

\section{Inclusion and Exclusion Criteria}

In selecting studies suitable for the review, the following selection inclusion and exclusion criteria were considered. Table 1 illustrates the criteria in detail.

\section{Search Strategy}

To capture as many relevant citations as possible, a wide range of published articles were searched using several electronic databases. The databases were ProQuest, EBSCOhost, Springer and Emerald Insight. All available articles up to 2018 were considered and the search was filtered to only for articles written in English. This effort resulted in 226 articles from which relevants studies were selected for the review. Their potential relevance was examined, and 131 were excluded as irrelevant. For the search, key words such as 'Psychological capital OR PsyCap AND educational organizations OR teachers' or 'Psychological capital OR PsyCap AND education' or 'Psychological capital OR PsyCap development' were used. Search details of the databases are reported in Table 2. The search was conducted on 703 articles on the ProQuest database, which resulted in 63 with key terms. An examination of 1401 articles on EBSCOhost resulted in identification of 95 articles. Among the 779 articles searched on the Springer database, 48 articles were identified. Out of 157 articles searched in Emerald, 20 articles were found relevant. 
Vol. 8, No. 3, 2019, E-ISSN: 2226-6348 @ 2019 HRMARS

Table 1. Inclusion and Exclusion criteria

\begin{tabular}{ll}
\hline Inclusion & Exclusion \\
\hline $\begin{array}{l}\text { Research topic and scope of the research; is it } \\
\text { relevant to the research question? }\end{array}$ & $\begin{array}{l}\text { Research topic and scope not relevant to the } \\
\text { research }\end{array}$ \\
$\begin{array}{l}\text { Concepts and definitions of terms are relevant } \\
\text { to research questions }\end{array}$ & $\begin{array}{l}\text { Concepts and definitions of terms are not } \\
\text { relevant to the research questions }\end{array}$ \\
$\begin{array}{l}\text { Qualitative studies, quantitative studies, } \\
\text { observations, case studies, experimental } \\
\text { studies, action research, reports on status of } \\
\text { the topic relevant to research questions, } \\
\text { conceptual and theoretical frameworks }\end{array}$ & \\
\hline $\begin{array}{l}\text { Studies on teachers, lecturers, students, } \\
\text { administrative staff }\end{array}$ & $\begin{array}{l}\text { Studies on people outside educational } \\
\text { organization }\end{array}$ \\
\hline $\begin{array}{l}\text { Articles published till } 2018 \\
\end{array}$
\end{tabular}

Table 2. Search Details

\begin{tabular}{llcc}
\hline $\begin{array}{l}\text { Databases } \\
\text { searched }\end{array}$ & \multicolumn{1}{c}{ Subheadings and key words used } & $\begin{array}{c}\text { Articles } \\
\text { searched }\end{array}$ & $\begin{array}{c}\text { Articles } \\
\text { identified }\end{array}$ \\
\hline ProQuest & $\begin{array}{l}\text { Psychological capital/PsyCap } \\
\text { Psychological capital/PsyCap in } \\
\text { educational organisation } \\
\text { Psychological capital/PsyCap AND } \\
\text { intervention AND development }\end{array}$ & 703 & 63 \\
EBSCOhost & $\begin{array}{l}\text { Psychological capital/PsyCap } \\
\text { Psychological capital/PsyCap in } \\
\text { academic setting AND development } \\
\text { Psychological capital/PsyCap AND } \\
\text { development }\end{array}$ & 1401 & \\
& $\begin{array}{l}\text { Psychological capital/PsyCap } \\
\text { Psychological capital /PsyCap in } \\
\text { academic setting AND teachers } \\
\text { Psychological capital/PsyCap AND } \\
\text { Students }\end{array}$ & & \\
\hline Emerald Insight & \begin{tabular}{l} 
Psychological capital/PsyCap \\
\hline
\end{tabular} & 779 & 48 \\
\hline
\end{tabular}


A step-by-step screening process further examined all studies identified. Figure 1 depicts the flow chart of the different stages of the literature search adopted from the PRISMA flow diagram (Moher, Liberati, Tetzlaff, Altman, \& Group, 2009). The initial step was evaluating the relevance of the identified articles based on the titles and abstracts. A total of 226 articles were screened for relevance, out of which 131 abstracts were excluded based on the relevance to the review objectives. Among the remaining 95 records, 17 records were duplicates and omitted from the review, leaving 78 articles eligible for full screening. The next step is to screen the articles eligible to be reviewed. 33 articles were excluded based due to the several reasons. The reasons those articles were excluded to be review is because (a) Using individual instrument of hope, optimism, self efficacy and resilience in the study and not PsyCap instrument and (b) written in language other than English. Based on the inclusion criteria, 45 articles with 42 quantitative studies and 3 qualitative studies were selected for data synthesis.

\section{Data Extraction}

The next step after identified the relevant articles to be reviewed was extraction. The types of data to be extracted are based on the review questions set ahead (Popay et al. 2006). This review aim at addressing the development and implementation of PsyCap within educational organization hence, relevant information to extract from the articles identified would include the sample population, the study setting, the study design as well as the interventions and the outcomes. 
Vol. 8, No. 3, 2019, E-ISSN: 2226-6348 @ 2019 HRMARS

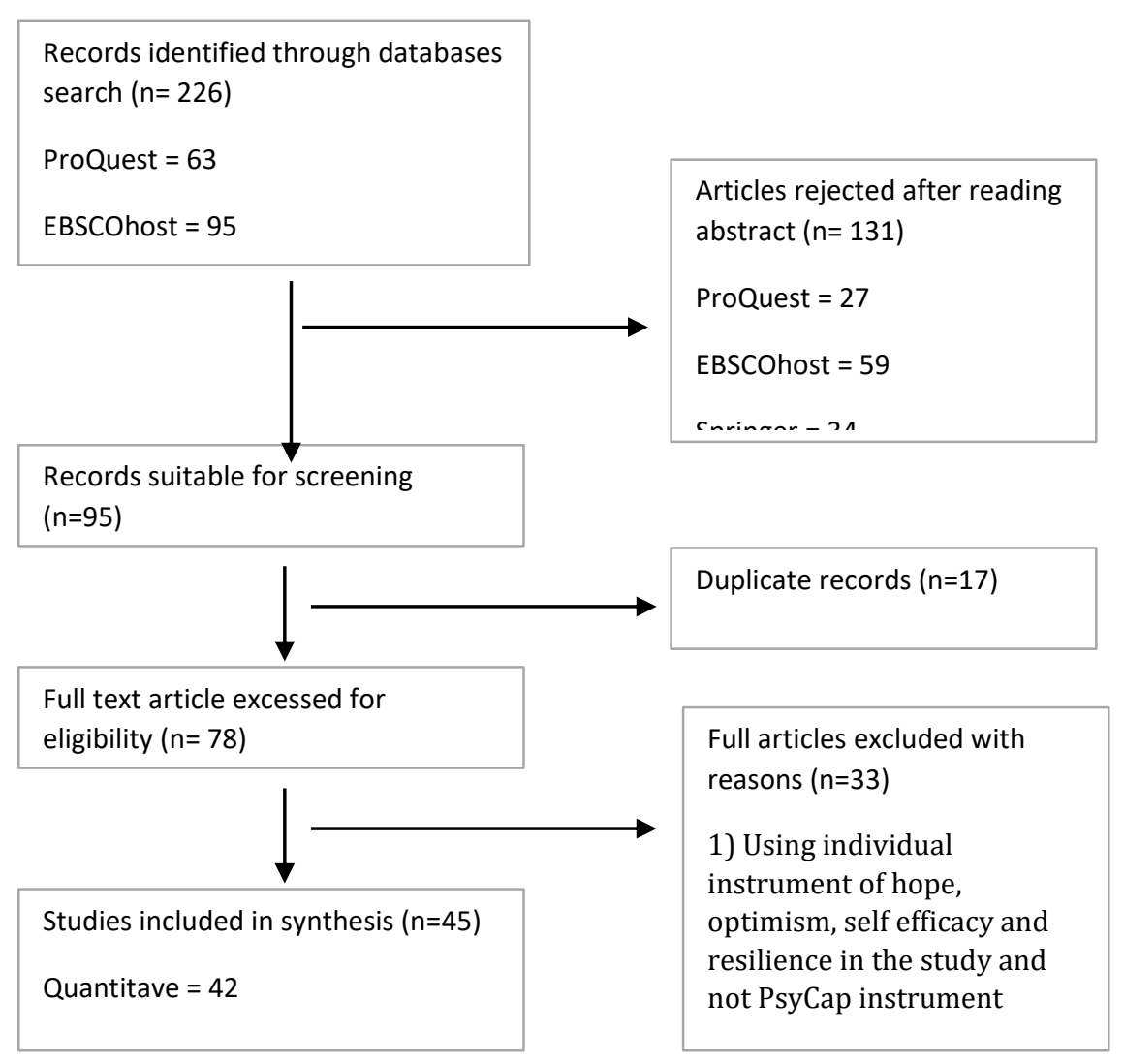

Figure 1. Flow chart of stages of literature search.

\section{Results}

The review were done based on several aspects which is the number of articles published over 10 years period, countries to which the articles published, the outcome variables distribution in relation to psychological capital, the sample used in the study, the sample size and the research design and instrument used in the study. Reviewed articles suggest that from the total of 45 articles, 8 of the articles, were published from China (Pan et al., 2015 \& Wang, 2015; Shen et al., 2014; Yin et al., 2016; Ma, 2014 \& Yan et al., 2016) following by the United States (Demerath et al., 2018; Goertzen \& Whitaker, 2015; Luthans, Luthans, \& Jensen, 2012; Luthans, Luthans, \& Palmer, 2016; McDowell, Huang, \& Caza, 2018; Selvaraj \& Bhat, 2018) which has the second highest number of articles published relating to psychological capital in educational organization. Large number of studies done on PsyCap in educational organization are originated from Asian countries in which after China, Turkey has the most number of articles publish following by Pakistan Kaya et al., 2018; Cimen \& Ozgan, 2018; Kalman \& Summak, 2017; Kaur \& Sandhu, 2016; Maitlo, Memon, \& Syed, 2017; Pan et al., 2015; Pu et al., 2017; Rehman et al., 2017; Simsek, 2014; Tosten \& Toprak, 2017; Tüzün, Çetin, \& Basim, 2018; Wang, Mei, \& Zhu, 2017; Yin et al., 2018; Yan, 2016; Ma et al., 2014 \& Shen et al., 2014) 


\section{Articles published based on country $(n=18)$}

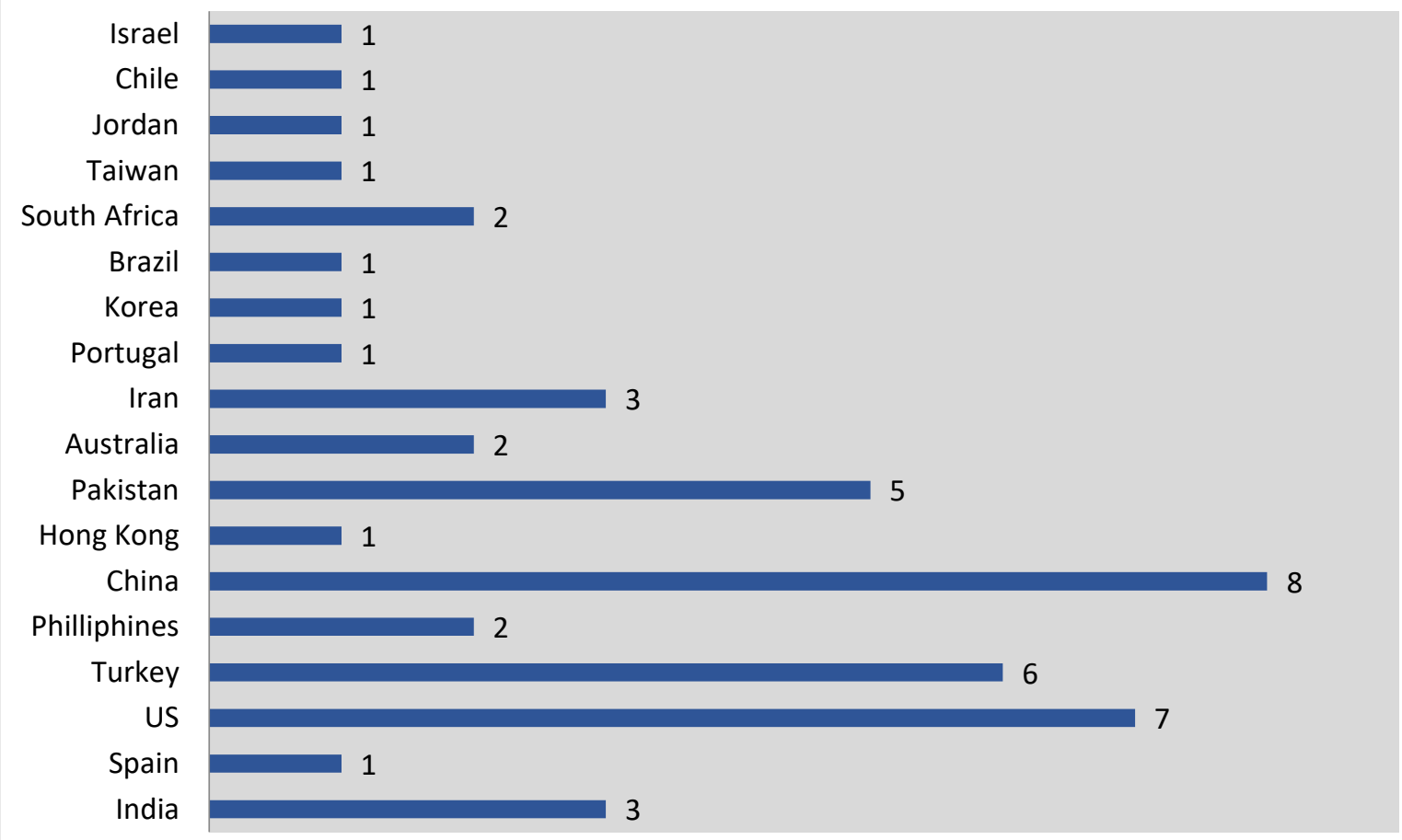

Figure 2: Articles on PsyCap in educational organization published based on country

Looking at the year of publication, there is an increment in the number of articles published starting from the year 2008 until 2014. In 2015 however, less articles were published as compared to the previous years. The following years in 2016, shows the highest number of articles published within the period of 10 years the articles being reviewed. Fairly high numbers of articles published in 2017 but less number of articles were published in the year 2018. 


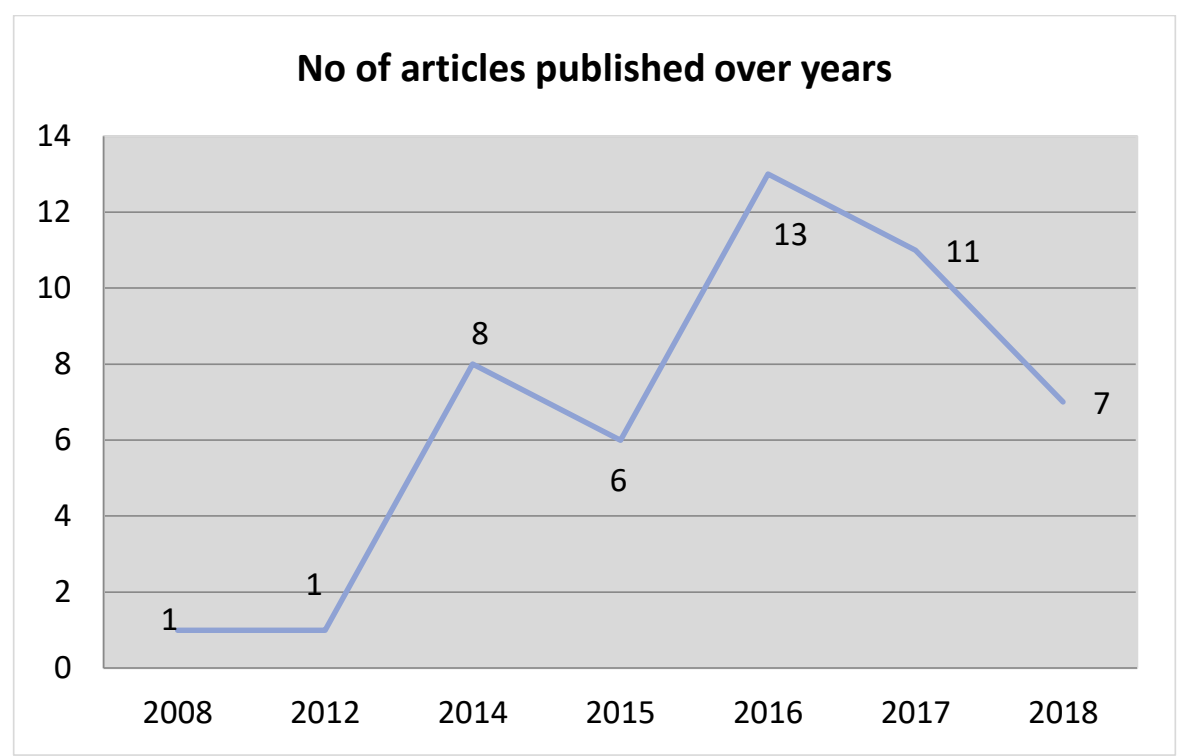

Figure 3: Numbers of articles published within 10 years

The reviewed articles suggest that academic performance has been the most studied variable in relation to PsyCap (Fig.4) (Carmona-Halty, Salanova, Llorens, \& Schaufeli, 2018; Datu et al., 2016; Luthans et al., 2012; Luthans et al., 2016; Ortega-Maldonado \& Salanova, 2018; Siu, Bakker, \& Jiang, 2014; You, 2016). Besides academic performance, stress among teachers and students has also received the attention among researcher to explore its relation to PsyCap (Rodrigues et al., 2017; Gautam \& Pradhan, 2018; Kaur \& Amin, 2017; Kaur \& Sandhu, 2016; Shen et al., 2014). The outcome of these studies shows that PsyCap is negatively correlated with stress and PsyCap moderate the relationship between stress and academic achievement. In the study that is conducted with teachers, it was found that teachers who have higher level of PsyCap shows lower rating of anxiety, depression and stress (Rodrigues et al., 2017) and PsyCap might be protective against depressive symptoms (Shen et al., 2014). In general, findings from the reviewed articles suggest that PsyCap is associate to a positive-related outcome and negatively linked to pathology and negative related variable (e.g., Stress, burnout). 
INTERNATIONAL JOURNAL OF ACADEMIC RESEARCH IN PROGRESSIVE EDUCATION AND DEVELOPMENT

Vol. 8, No. 3, 2019, E-ISSN: 2226-6348 @ 2019 HRMARS

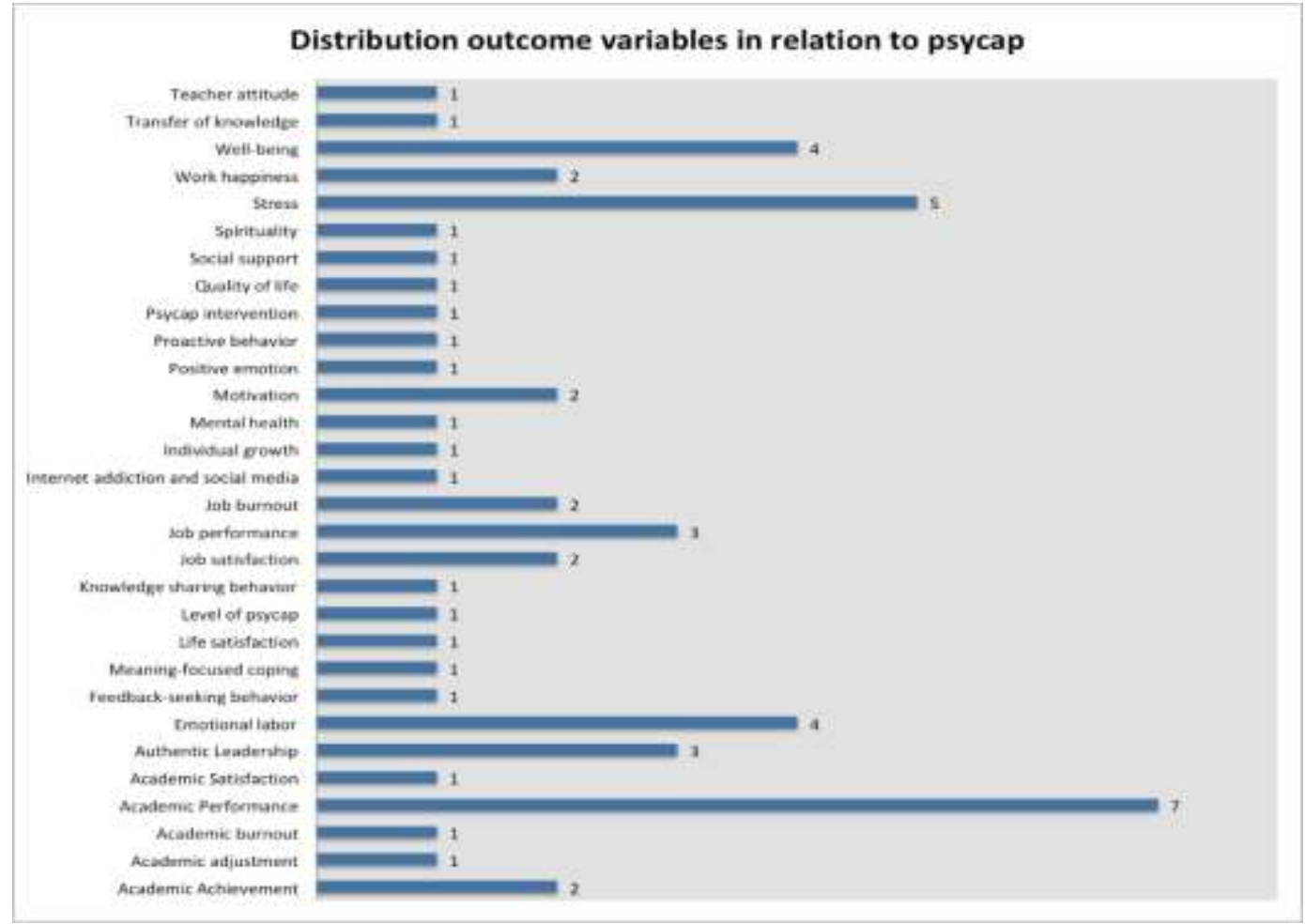

Figure 4: Distribution of outcome variable in relation to PsyCap

Figure 5 shows the type of sample used in the study exploring the PsyCap with people within educational organization. Findings from the review suggest that university/college students has been selected in most studies following by teachers and lecturers while limited number of studies were done with administrative staff.

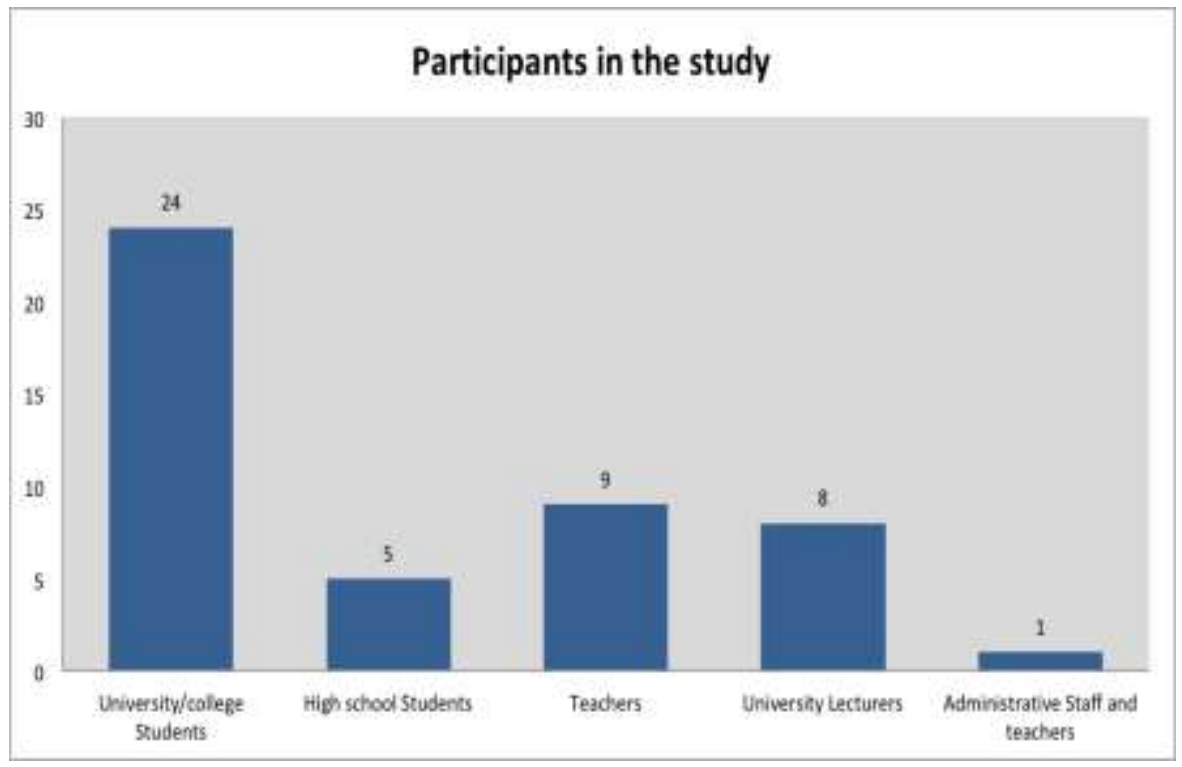

Figure 5: Participants selected in the study 
Through the review, it was found that numerous studies used a large number of samples (Fig. 6), which are more than 400 in researching PsyCap with selected variables. This indicated that researcher has opt for a quantitative measure than getting in depth understanding through qualitative approach (Fig. 7). Out of the total number of the study reviewed, only 3 studies done qualitatively which suggest more qualitative research on PsyCap is needed.

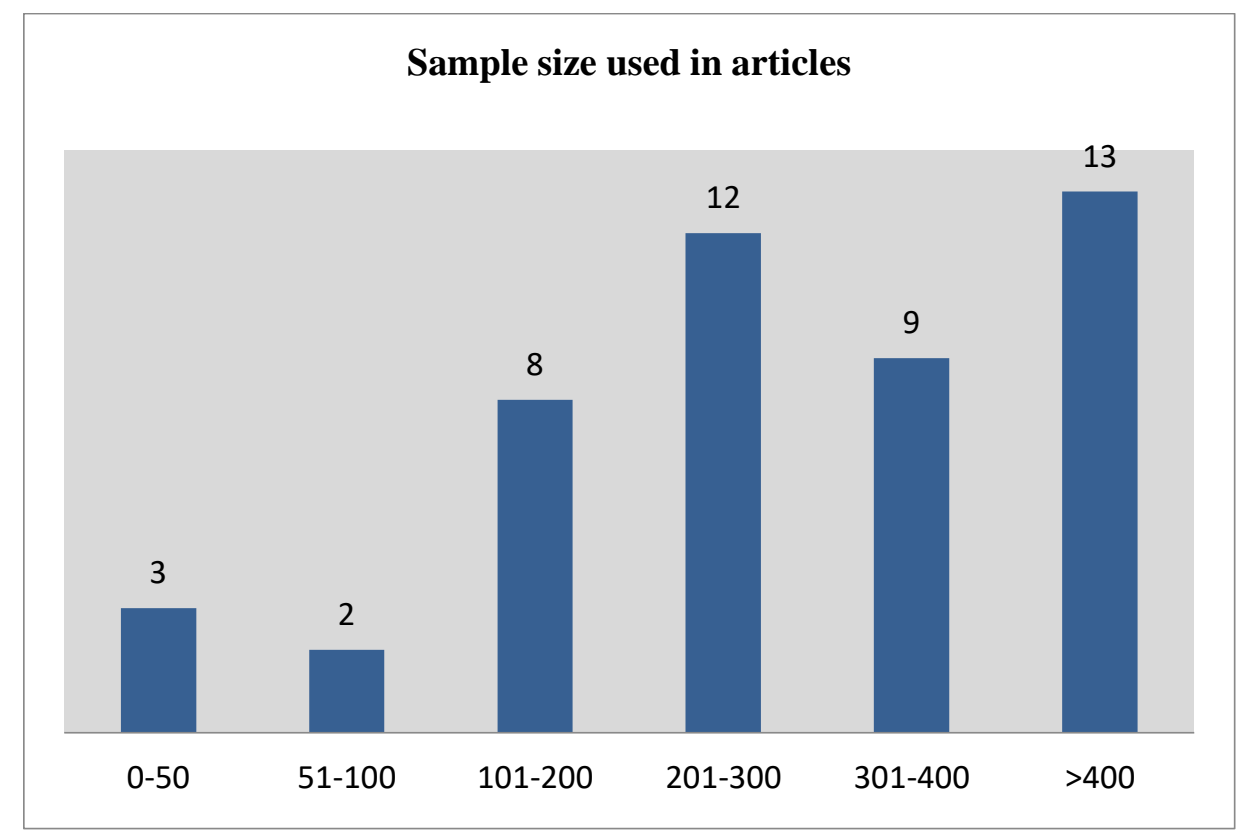

Figure 6: Sample size used in the study

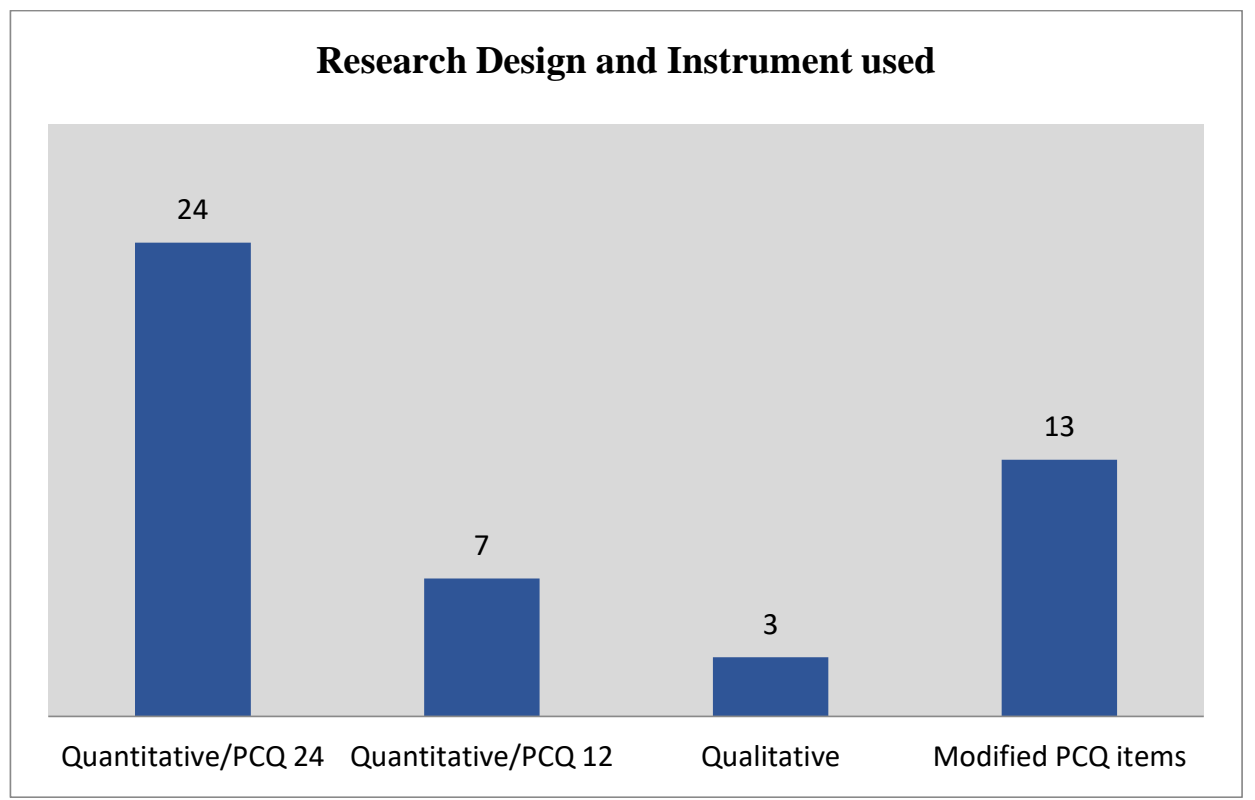

Figure 7: Type of research design and instrument used in the study 
DEVELOPMENT

Vol. 8, No. 3, 2019, E-ISSN: $2226-6348$ @ 2019 HRMARS

\section{Research Gaps and Research Priorities}

Taken together, the identified articles shows that research on PsyCap within educational organization is still in its early stages and more study which looking at different variables is needed in order to get a great understanding about how this construct of PsyCap have and impact on individual. On the methodological part, studies done using qualitative design somehow limited with out of all the articles being reviewed, only three articles were identified done qualitatively. Those studies aims to get a deeper understanding about PsyCap by exploring the dimension of PsyCap (Demerath et al., 2018) gaining a greater insight into the factors that contribute to teachers' PsyCap (Cimen \& Ozgan, 2018) and exploring teachers' perception to the effect of PsyCap through teacher-targeted intervention as means to enhance their positive psychological capacities (Kalman \& Summak, 2017). Many of the other studies were based on self-report measure of which using the original 24-item Psychological Capital Questionnaire (PCQ), the shorter version of PCQ 12-item or the modified PCQ item (Ma et al., 2014; Safari, Mahmoodi, \& Amirianzadeh, 2017; Selvaraj \& Bhat, 2018; You, 2016) developed to suit the study objectives and participants selected for the study. Hence, future research should consider on adopting more qualitative research in order to get a different perspective of the PsyCap construct and how is the construct being developed within the people in educational organization. The choice of sample to be included in the study should also be varied and not limited to just teachers, lecturers and students. As noted from the review findings, only one study was done administrative staff (Williams, Kern, \& Waters, 2015) while the other was done with students, teachers and university lecturers. More study on PsyCap should be done with principal, people who support the schools performance such as district officer, people who is working in ministry of education and et cetera. These people should be considered as the sample in order to get a more diversed findings of PsyCap as well as in depth understanding about this construct.

In addition, only few studies have been conducted in Southeast Asia countries, let alone Malaysia. No study on PsyCap so far, has been identified conducted in Malaysia. A lot of the studies have been done in the western context. This of course, suggests that study on PsyCap should be done considering Asian context, Malaysia specifically as it could potentially suggest an interesting finding.

\section{Conclusion and Future Directions}

This review examined published literature on the use and development of PsyCap within educational organization. Findings from the review revealed great promise of PsyCap as a way to flourish an individual as well as direct people to a positive outcome in work and life generally. The review also revealed a number of quantitative studies examining the relation of PsyCap to several variables and to see how it links to a positive outcome such as increase students' academic performance, academic achievement, happiness, job satisfaction and etc rather than negative outcome. Qualitative studies on PsyCap however, were limited. Minimal attention has been directed towards how the construct of PsyCap is being developed within individual.

There is a need to understand individual experience in educational organization and to identify if they able to develop PsyCap that lead to a positive outcome such as greater life satisfaction, happiness, better work performance and etc. about PsyCap were develop is not well 
documented. This should be considered as an essential research priority. More work needed to ensure psychological capacities needed by individual in educational organization.

Understanding how the construct of PsyCap is developed will contribute to the continuing discussion of positive psychology discipline. Examining the experience of people in educational organization is important to understand how people outside the industrial organization develop PsyCap and how it is crucial as psychological capacities that is needed to be develop in individual. Therefore, more studies are needed looking at the development of PsyCap in educational organization. Studies can be framed within the view of experiences, such as phenomenological study, analysis of multiple perspective and specific context that contribute to development of PsyCap. Such perspective will provide a better understanding of PsyCap construct and not just limited to the self-report measure.

\section{References}

Avey, J. B., Wernsing, T. S., \& Luthans, F. (2008). Can positive employees help positive organizational change? Impact of psychological capital and emotions on relevant attitudes and behaviors. The Journal of Applied Behavioral Science, 44(1), 48-70.

Avey, J. B., Luthans, F., \& Jensen, S. M. (2009). Psychological capital: A positive resource for combating employee stress and turnover. Human Resource Management, 48, 677-693. doi:10.1002/hrm.20294

Avey, J. B., Luthans, F., \& Youssef, C. M. (2010). The additive value of positive psychological capital in predicting work atti- tudes and behaviors. Journal of Management, 36, 430-452. doi:10.1177/0149206308329961

Alipoor, A., Saffarinia, M., Forushani, G. H., Aghaalikhani, A. M., \& Akhoondi, N. (2013). Investigating the effectiveness of Luthans' psychological capital intervention on burnout of experts working in Iran Khodro Diesel Company. Quarterly journal of medicine, 4(3), 30-41.

Beal, L., Stavros, J. M., \& Cole, M. L. (2013). Effect of psychological capital and resistance to change on organisational citizenship behaviour. SA Journal of Industrial Psychology/SA Tydskrif vir Bedryfsielkunde, 39(2), 1-11.

Bandura, A. (1997). Self-efficacy: The exercise of control. New York: Freeman.

Bandura, A. (1977). Self-efficacy: Toward a unifying theory of behavioral change. Psychological Reveiw, 84, 191-215.

Bakker, A. B., \& Demerouti, E., (2007) The Job Demands-Resources model: state of the Art. Journal of Managerial Psychology, Vol. 22 Issue: 3, pp.309-328

Carmona-Halty, M., Salanova, M., Llorens, S., \& Schaufeli, W. B. (2018). How Psychological Capital Mediates Between Study-Related Positive Emotions and Academic Performance. Journal of Happiness Studies, 1-13. https://doi.org/10.1007/s10902-018-9963-5

Cimen, I., \& Ozgan, H. (2018). Contributing and damaging factors related to the psychological capital of teachers: A qualitative analysis. Issues in Educational Research, 28(2), 308-328.

Datu, J. A. D., King, R. B., Valdez, J. P. M., Alfonso, J., King, R. B., \& Valdez, J. P. M. (2016). Psychological capital bolsters motivation, engagement, and achievement: Crosssectional and longitudinal studies. The Journal of Positive Psychology, 9760(November), 1-11. https://doi.org/10.1080/17439760.2016.1257056 
INTERNATIONAL JOURNAL OF ACADEMIC RESEARCH IN PROGRESSIVE EDUCATION AND DEVELOPMENT

Vol. 8, No. 3, 2019, E-ISSN: 2226-6348 @ 2019 HRMARS

Demerath, P., Lynch, J., Davidson, M., Anthropology, S., Quarterly, E., Privilege, W., ... Davidson, M. (2018). Dimensions of Psychological Capital in a U . S . Suburb and High School: Identities for Neoliberal Times Published by: Wiley on behalf of the American Anthropological Association Stable URL: http://www.jstor.org/stable/25166669 Dimensions of Psychologi, 39(3), 270-292. https://doi.org/10.1111/j.I5481492.2008.00022.x.270

Goertzen, B. J., \& Whitaker, B. L. (2015). Development of psychological capital in an academicbased leadership education program. Journal of Management Development, 34(7), 773786. https://doi.org/10.1108/JMD-07-2013-0100

Gautam, P., \& Pradhan, M. (2018). Psychological capital as moderator of stress and achievement, 9(1), 22-28. https://doi.org/http://dx.doi.org/10.15614/ijpp.v9i01.n737

Khan, K. S., Kunz, R., Kleijnen, J., \& Antes, G. (2003). Five steps to conducting a systematic review. Journal of the Royal Society of Medicine, 96(3), 118-121.

Kalman, M., \& Summak, M. S. (2017). Revitalizing the HERO within teachers: An analysis of the effects of the PsyCap development training. The Qualitative Report, 22(3), 655-682. https://doi.org/10.1007/s00702-006-0556-9

Kaur, J., \& Amin, S. (2017). Psychological capital and stress among school students. Indian Journal of Positive Psychology, 8(4), 495-499.

Kaur, J., \& Sandhu, K. K. (2016). Psychological capital in relation to stress among university students, 7(3), 323-326.

Luthans, F. (2002). Positive organizational behavior: Developing and managing psychological strengths. Academy of Management Executive, 16(1), 57-72.

https://doi.org/10.5465/AME.2002.6640181

Luthans, F. (2002). The need for and meaning of positive organizational behavior. Journal of Organizational Behavior, 23, 695-706.

Luthans, F., Avolio, B. J., Walumbwa, F., \& Li, W. (2005). The psychological capital of Chinese workers: Exploring the relationship with performance. Management and Organization Review, 1, 247-269. doi:10.1111/j.1740-8784.2005.00011.x

Luthans, F., Avey, J. B., Avolio, B. J., Norman, S. M., \& Combs, G. M. (2006). Psychological capital development: Toward a micro-intervention. Journal of Organizational Behaviour, 27, 387393.

Luthans, F., \& Jensen, S.M. (2005). The linkage between psychological capital and commitment to organizational mission - A study of nurses. Journal of Nursing Administration, 35, 304310.

Luthans, F., Avolio, B. J., Avey, J. B., Norman, S. M. (2007a) Positive Psychological Capital: Measurement and Relationship with Performance and Satisfaction. Personnel Psychology. 60 (3). pp. 541-572. DOI: 10.1111/j.1744-6570.2007.00083.x

Luthans F, Avolio BJ, Avey JB, Norman SM (2007). Positive psychological capital: Measurement and relationship with performance and satisfaction. Pers Psychol. 60: 541-572. 20.

Luthans, F., Youssef-Morgan, C., \& Avolio, B. J. (2007b). Psychological capital: Developing the human competitive edge. New York: Oxford University Press. 
INTERNATIONAL JOURNAL OF ACADEMIC RESEARCH IN PROGRESSIVE EDUCATION AND DEVELOPMENT

Vol. 8, No. 3, 2019, E-ISSN: 2226-6348 @ 2019 HRMARS

Luthans, F, Avey J.B., Patera J.L. (2008). Experimental analysis of a web-based training intervention to develop positive psychological capital. Acad Manag Learn \& Edu. 7: 209221.

Luthans, B. C., Luthans, K. W., \& Jensen, S. M. (2012). The Impact of Business School Students' Psychological Capital on Academic Performance. Journal of Education for Business, 87(5), 253-259. https://doi.org/10.1080/08832323.2011.609844

Luthans, F. and Youssef-Morgan, C. (2017), "Psychological capital: an evidence-based positive approach", Annual Review of Organizational Psychology and Organizational Behavior, Vol. 4, pp. 339-366.

Luthans, K. W., Luthans, B. C., \& Palmer, N. F. (2016). A positive approach to management education: The relationship between academic PsyCap and student engagement. Journal of Management Development, 35(9), 1098-1118. https://doi.org/10.1108/JMD-06-20150091

Luthans, B. C., Luthans, K. W., \& Jensen, S. M. (2012). The Impact of Business School Students' Psychological Capital on Academic Performance. Journal of Education for Business, 87(5), 253-259. https://doi.org/10.1080/08832323.2011.609844

Madden, L. T, (2013). impact of middle managers' activity, role conflict, and psychological capital on their job performance and turnover intentions, PhD diss., University of Tennessee, Retrieved from http://trace.Tennessee.edu/ utk_graddiss/1756

Mahmoudvand, M. (2013) . Investigating the relationship between mental health and depression among third grade secondary school female students in Zahedan area. 6th International Congress on Child and Adolescent Psychiatry. Tabriz University of Medical Sciences and Health Services.

Mortazavi, M., Aghae, E., Jamali, S., \& Abedi, A. (2012). Meta-analysis of comparing the effectiveness of pharmacological treatment and psychological interventions on the rate of depression symptoms. Journal of culture of counseling and psychotherapy, 10, 1-32.

Moher, D., Liberati, A., Tetzlaff, J., Altman, D. G., \& Group, T. P. (2009). Preferred reporting items for systematic reviews and meta-analyses: The PRISMA statement. PLoS Medicine, 6(7), e1000097. doi:10.1371/journal.pmed.1000097

Ma, H., Guo, Y. \& Xu, F. (2014). Positive Psychological Capital: A New Approach To Social Support And Subjective Well-Being. Journal of Social Behavior And Personality, 2014, 42(1), 135144.

McDowell, J., Huang, Y.-K., \& Caza, A. (2018). Does identity matter? An investigation of the effects of authentic leadership on student-athletes' psychological capital and engagement. Journal of Sport Management, 32(3), 227-242. https://doi.org/10.1123/jsm.2017-0241

Maitlo, A. A., Memon, S. B., \& Syed, S. (2017). Influence of Psychological Capital on Knowledge Sharing Behaviour in Research Fellows of Public Sector Universities. Journal of Business Strategies, 11(2), 1-20.

Nafei, W. (2015), "The effects of psychological capital on employee attitudes and employee performance: a study on teaching hospitals in Egypt", International Journal of Business and Management, Vol. 10 No. 3, pp. 249-270.

Ortega-Maldonado, A., \& Salanova, M. (2018). Psychological capital and performance among undergraduate students: the role of meaning-focused coping and satisfaction. Teaching 
INTERNATIONAL JOURNAL OF ACADEMIC RESEARCH IN PROGRESSIVE EDUCATION AND DEVELOPMENT

Vol. 8, No. 3, 2019, E-ISSN: 2226-6348 @ 2019 HRMARS

in Higher Education, 23(3), 390-402. https://doi.org/10.1080/13562517.2017.1391199

Popay, J., Roberts, H., Sowden, A., Petticrew, M., Arai, L., Rodgers, M., Duffy, S. (2006). Guidance on the conduct of narrative synthesis in systematic reviews. A product from the ESRC Methods Programme, 2006(April), 211-219. doi:10.1111/j.1523-536x.1995tb00261.x

Pan, B., Shen, X., Liu, L., Yang, Y., \& Wang, L. (2015). Factors associated with job satisfaction among university teachers in northeastern region of China: A cross-sectional study. International Journal of Environmental Research and Public Health, 12(10), 12761-12775.

https://doi.org/10.3390/ijerph121012761

$\mathrm{Pu}$, J., Hou, H., Ma, R., \& Sang, J. (2017). The effect of psychological capital between work-family conflict and job burnout in Chinese university teachers: Testing for mediation and moderation. Journal of Health Psychology, 22(14), 1799-1807.

https://doi.org/10.1177/1359105316636950

Rahimi, F., Arizi, H., Noori, A., \& Namdari, K. (2012). The relationship between psychological capital in the workplace and employees' passion for their work in the organization. Quarterly journal of occupational and organizational counseling, 4(12), 9-30.

Rodrigues, R. I., Carochinho, B. J.-A., \& Rendeiro, O. M. M. (2017). the Impact of Positive Psychological Capital on the Psychological Distress of Primary and Secondary Education Teachers. Psique, Journal of Research Centre for Psychology of the Universidade Autonoma de Lisboa, 12, 40-56.

Rehman, S. U. R, Qingren, C., Latif, Y., \& Iqbal, P. (2017). Impact of psychological capital on occupational burnout and performance of faculty members. International Journal of Educational Management, 31(4), 455-469. https://doi.org/10.1108/IJEM-01-2016-0011

Simons, J. C., \& Buitendach, J. H. (2013). Psychological capital, work engagement and organisational commitment amongst call centre employees in South Africa. SA Journal of Industrial Psychology/SA Tydskrif vir Bedryfsielkunde, 39(2), 1-12.

Seligman, M. (1998). Positive social science. APA Monitor, 29(2), 5.

Stajkovic, A. D., \& Luthans, F. (1998). Self-efficacy and work-related performance: A metaanalysis. Psychological Bulletin, 124, 240-261.

Siddaway, A. (2014). What is a systematic literature review and how do I do one?.

Strech, D., \& Sofaer, N. (2012, February). How to write a systematic review of reasons. Journal of Medical Ethics. Institute of Medical Ethics. doi:10.1136/medethics-2011-100096

Shen, X., Yang, Y. L., Wang, Y., Liu, L., Wang, S., \& Wang, L. (2014). The association between occupational stress and depressive symptoms and the mediating role of psychological capital among Chinese university teachers: A cross-sectional study. BMC Psychiatry, 14(1), 1-8. https://doi.org/10.1186/s12888-014-0329-1

Carmona-Halty, M., Salanova, M., Llorens, S., \& Schaufeli, W. B. (2018). How Psychological Capital Mediates Between Study-Related Positive Emotions and Academic Performance. Journal of Happiness Studies, 1-13. https://doi.org/10.1007/s10902-018-9963-5

Safari, F., Mahmoodi, M., \& Amirianzadeh, M. (2017). Forecast quality of life in connection with psychological capital and family communication patterns in students, 8(2), 108-112.

Selvaraj, P. R., \& Bhat, C. S. (2018). Predicting the mental health of college students with psychological capital. Journal of Mental Health, 27(3), 279-287. https://doi.org/10.1080/09638237.2018.1469738 
INTERNATIONAL JOURNAL OF ACADEMIC RESEARCH IN PROGRESSIVE EDUCATION AND DEVELOPMENT

Vol. 8, No. 3, 2019, E-ISSN: 2226-6348 @ 2019 HRMARS

Simsek, E. (2014). The Role of Internet Addiction and Social Media Membership on University Students' Psychological Capital, 5(3), 239-256.

Siu, O. L., Bakker, A. B., \& Jiang, X. (2014). Psychological Capital Among University Students: Relationships with Study Engagement and Intrinsic Motivation. Journal of Happiness Studies, 15(4), 979-994. https://doi.org/10.1007/s10902-013-9459-2

Tosten, R., \& Toprak, M. (2017). Positive psychological capital and emotional labor: A study in educational organizations. Cogent Education, 4(1), 1-12.

https://doi.org/10.1080/2331186X.2017.1301012

Tüzün, I. K., Çetin, F., \& Basim, H. N. (2018). Improving job performance through identification and psychological capital. International Journal of Productivity and Performance Management, 67(1), 155-170. https://doi.org/10.1108/IJPPM-03-2016-0060

Wang, Y., Mei, J., \& Zhu, Y. (2017). Feedback-Seeking Behavior: Feedback Cognition As a Mediator. Social Behavior and Personality, 45(7), 1099-1112.

https://doi.org/10.2224/sbp.6055

Williams, P., Kern, M. L., \& Waters, L. (2015). A Longitudinal Examination of the Association Between Psychological Capital, Perception of Organizational Virtues and Work Happiness in School Staff. Psychology of Well-Being, 5(1), 5. https://doi.org/10.1186/s13612-0150032-0

Yin, H., Wang, W., Huang, S., \& Li, H. (2018). Psychological Capital, Emotional Labor and Exhaustion: Examining Mediating and Moderating Models. Current Psychology, 37(1), 343-356. https://doi.org/10.1007/s12144-016-9518-z

You, J. W. (2016). The relationship among college students' psychological capital, learning empowerment, and engagement. Learning and Individual Differences, 49, 17-24.

https://doi.org/10.1016/j.lindif.2016.05.001

Yan, L. (2016). Dynamic Analysis of Psychological Capital Impact on Individual Growth of College Students Based on Data Mining. Iberian Journal of Information Systems and Technologies, 259-269. 